УДК 796.011.1

https://doi.org/10.36906/FKS-2021/48

Катканова И.Н.

ORCID: 0000-0002-5663-1632;

Егоренко Д.С.

Вологодский государственный университет

2. Вологда, Россия

\title{
ЗНАЧЕНИЕ ЗАНЯТИЙ ФИЗИЧЕСКОЙ КУЛЬТУРОЙ В ПРИВИВАНИИ ИНТЕРЕСА К СПОРТИВНОЙ ДЕЯТЕЛЬНОСТИ ВНЕ УЧЕБНОГО ПРОЦЕССА
}

Аннотация. Данная работа посвящена оценке влияния занятий физической культурой в прививании интереса к спортивной деятельности вне учебного процесса, в частности выделены основные проблемы и пути их решений. В статье авторами затрагивается тема повышения у студентов высших учебных заведений интереса к занятиям физической культурой путём замещения конкретно физических упражнений на игровую спортивную деятельность, определяется роль преподавателя в условиях новых способов ведения занятий. На основе проведения исследования, анализа литературных источников, рассмотрены проблемы мотивации к занятиям физической культурой в СОШ. Полученные результаты позволили авторам оценить роль занятий физической культуры для дальнейшей самостоятельной работы в данной области.

Ключевые слова: физическая культура, мотивация, здоровый образ жизни, интерес.

Katkanova I.N. ORCID: 0000-0002-5663-1632;

Egorenko D.S.

Vologda State University

Vologda, Russia

\section{THE IMPORTANCE OF PHYSICAL EDUCATION IN INSTILLING INTEREST IN SPORTS ACTIVITIES OUTSIDE THE EDUCATIONAL PROCESS}

Annotation. This work is devoted to assessing the impact of physical education in instilling interest in sports activities outside the educational process, in particular, the main problems and ways of their solutions are highlighted. In the article, the authors touch upon the topic of increasing the interest of students of higher educational institutions in physical education by replacing specific physical exercises with game sports activities, the role of the teacher in the conditions of new ways of conducting classes is determined. On the basis of the research, the analysis of literary sources, the problems of motivation for physical education in secondary schools are considered. The obtained results allowed the authors to evaluate the role of physical education classes for further independent work in this field.

Keywords: physical culture, motivation, healthy lifestyle, interest. 
В условиях постоянного развития российского образования большое внимание уделяется исправлению системы физического воспитания обучающихся. Во многих научных работах, диссертациях за последние десять лет, указывается на то, что начиная с начального образования в СОШ, отношение обучающихся к физкультурной активности ежегодно ухудшается, становятся негативным в старших классах.

По данным Всероссийского научно-исследовательского института физической культуры, более $80 \%$ отечественных старшеклассников и около $35 \%$ обучающихся Вузов выразили своё отрицательное отношение к урокам физической культуры. Причина кроется в отсутствие у обучающихся устойчивого интереса к этим занятиям. Проявляет или не проявляет ученик интерес к занятиям физической культурой - зависит от многих причин. Мотивы могут быть разными: учебно-познавательные, результативные, социально-значимые и т. д. Мотивация занятий физической культурой сейчас практически незаметна, в большинстве учебных заведений они проводятся один-два раза в неделю, потому и эффект от них ожидаемый: лишь единицы из сотен обучающихся занимаются физической культурой самостоятельно. По статистическим данным материалов «Россия в цифрах. 2020», в Вологодской области в возрасте 15-20 лет полностью самостоятельно занимаются физической культурой и спортом лишь $21 \%$.

По ряду причин, которые в большинстве остаются нерешенными, интерес к занятиям физкультурой отсутствует, на занятия ученики ходят не по собственному желанию, а скорее потому что «надо». Во многих высших учебных заведениях «студенты не имеют достаточной любви к дисциплине, несмотря на её заметные плюсы. В большинстве случаев это связано с тем, что обучающимся вовсе не интересны физические нагрузки, так как они не ассоциируют себя с активной физической деятельностью, если это не предусмотрено непосредственно их желаемой профессией [2]. Ученику не хочется посещать обязательные занятия, соответственно добровольно заниматься он также не станет, на первый план выходят простые причины: «Не достаточно свободного времени». Возможно, дело кроется не только в отсутствии свободного времени на саморазвитие, но и недостаток интереса у учеников к занятиям, что как раз необходимо решать.

Прежде чем решать вопрос о роли занятий физической культурой в прививании интереса к спортивной деятельности во вне учебное время, мы выяснили, что отторгает обучающихся от занятий физическими упражнениями, прежде всего методы преподавания уроков физкультуры. Большинство преподавателей и учителей не стремятся к привитию интереса к подвижным играм и т. д. Когда занятия по физической культуре по программе проводятся 1-2 раза в неделю, то работа преподавателя заключается в том, чтобы научить обучающихся заниматься самостоятельно. В ходе наших исследований, мы выяснили, что в некоторых учебных заведениях ещё сохраняется проведение занятий, ориентированных на выполнение нормативов, что в дальнейшем способствует снижению интереса к занятиям. Получение неудовлетворительных отметок, приводит к ассоциации физкультуры с чем-то не самым лучшим, пропадает интерес и желание бегать, прыгать, кувыркаться. На наш взгляд задача педагога должна заключаться не только в том, чтобы просто выдать учебную программу, но и в развитии интереса к своему предмету. Делается это разными способами, цель которых будет в повышении мотивации и интереса к спортивной деятельности, ведь только в таком случае ученики решаться заниматься спортом не только на уроках физкультуры. Данные занятия должны не только развивать детей физически, но и привить любовь к спорту, сейчас есть первостепенные задачи, мешающие детям поднять мотивацию к внеурочной физкультурной и спортивной деятельности. 
Таким образом, анализируя многие научные, литературные источники, мы определили три основные, на наш взгляд проблемы в мотивации. Во-первых - отсутствие понимая важности физической культуры и спорта для здоровья человека, его образования, труда и творчества. Решение проблемы может быть разносторонним. Например: лекции о значимости спорта в жизни человека с вовлечением в дискуссию обучающихся. Во время таких лекций ученики могут самостоятельно прийти к выводам, которые изначально собирался озвучить преподаватель. Большинство психологов отмечают, что подобные теоретические занятия имеют большее влияние посредством испытываемых эмоций в процессе споров и отстаивания собственного мнения. Именно такие лекции помогут объяснить обучающимся, какую пользу для здоровья и творчества несут в себе занятия физкультурой.

Во-вторых - нулевой интерес к подвижным играм, участию в спортивных соревнования. В этой же ситуации решение лежит на поверхности: частое и регулярное проведение подвижных игр во время занятий. В большинстве своем преподаватели считают эти игры лишь развлечением, тогда как психологи утверждают, что посредством физической игровой деятельности ученик получает позитивные эмоции, от чего ему хочется продолжать данные действия и в будущем. Помимо самых привычных игр, таких как волейбол и футбол, стоит ввести различные эстафеты на уровне образовательного учреждения, показать обучающимся дух соперничества и сплоченности команды. С подобных занятий ученик будет уходить в хорошем расположении духа, а попробовав себя в различных спортивных видах, выберет наиболее подходящий, который больше нравится, после чего возможно запишется в спортивные секции. В рекомендациях детского физиолога Ю.Ф. Змановского отдельно выделяется: «Создание условий для преобладания положительных эмоций во всех видах двигательной деятельности», чему как раз и могут послужить игры.

В-третьих - нежелание стремиться к здоровому образу жизни, нет отвращения к вредным привычкам. Для решения этого вопроса, мы считаем, что, безусловно, стоит выделить лекционные часы и попытаться донести до учеников, что вредные привычки действительно несут серьезные последствия, о которых можно узнать из различных источников и СМИ.

Таким образом, мы можем сделать вывод о том, что правильно построенное занятия по физической культуре, с правильным отношением к обучающимся оставит после себя не только положительные эмоции, но и желание дальше развиваться в спортивных сферах деятельности. Занятия физкультурой начинаются еще в дошкольных учреждениях, где дети знакомятся с различными видами упражнений. В школах уже имеется возможность подвижной игры с мячом, и именно такие занятия влияют на интерес к физической деятельности вне учебы. Ученик, получая удовольствие от занятий каким-либо видом спорта, продолжит заниматься им и дальше. А также «физическое воспитание в дошкольных образовательных учреждениях должно соответствовать всем новым условиям и обеспечивать потребности детей в активной физической деятельности» [1]. Сложившийся положительный эффект от занятий физической культурой возможно будет перенесен и учебную деятельность в высшей школе, где положительное впечатление от деятельности вызовет у студентов желание заниматься физической активностью чаще. Занятия физкультурой имеют колоссальное влияние на мотивацию учеников к дальнейшему спортивному будущему, однако, вопрос стоит в умении заинтересовать, замотивировать и дать толчок к этому будущему, а такой толчок как раз должен проявиться на учебной деятельности. 


\section{Литература}

1. Гедерт В.А., Катканова И.Н. Мотивация к занятиям физической культурой детей дошкольного возраста // Традиции и инновации физического воспитания обучающихся образовательных организаций: Материалы региональной научно-практической конференции. Вологда, 2019. С. 15-18.

2. Катканова И.Н., Логинов Н.Е., Хомякова В.Н. Прививание спортивного духа обучающихся в высших учебных заведениях при помощи спортивной игровой деятельности // Молодежь и наука: Материалы международной научно-практической конференции. Нижний Тагил, 2020. С. 507-509.

(С Катканова И.Н., Егоренко Д.С., 2021 